\title{
Montmorillonite-surfactant hybrid particles for modulating intestinal P-glycoprotein- mediated transport
}

Nielsen, Rasmus Blaaholm; Kahnt, Ariane; Dillen, Lieve; Wuyts, Koen; Snoeys, Jan; Nielsen, Ulla Gro; Holm, René; Nielsen, Carsten Uhd

Published in:

International Journal of Pharmaceutics

DOI:

10.1016/j.ijpharm.2019.118696

Publication date:

2019

Document Version

Peer reviewed version

Citation for published version (APA):

Nielsen, R. B., Kahnt, A., Dillen, L., Wuyts, K., Snoeys, J., Nielsen, U. G., Holm, R., \& Nielsen, C. U. (2019).

Montmorillonite-surfactant hybrid particles for modulating intestinal P-glycoprotein-mediated transport.

International Journal of Pharmaceutics, 571, [118696]. https://doi.org/10.1016/j.ijpharm.2019.118696

\section{General rights}

Copyright and moral rights for the publications made accessible in the public portal are retained by the authors and/or other copyright owners and it is a condition of accessing publications that users recognise and abide by the legal requirements associated with these rights.

- Users may download and print one copy of any publication from the public portal for the purpose of private study or research.

- You may not further distribute the material or use it for any profit-making activity or commercial gain.

- You may freely distribute the URL identifying the publication in the public portal.

Take down policy

If you believe that this document breaches copyright please contact rucforsk@kb.dk providing details, and we will remove access to the work immediately and investigate your claim. 


\section{Montmorillonite-surfactant hybrid particles for modulating}

3 Rasmus Blaaholm Nielsen ${ }^{1}$, Ariane Kahnt ${ }^{2}$, Lieve Dillen ${ }^{2}$, Koen Wuyts ${ }^{2}$, Jan Snoeys ${ }^{2}$, Ulla Gro

4 Nielsen ${ }^{1}$, René Holm ${ }^{3,4}$, Carsten Uhd Nielsen ${ }^{1 *}$

$5 \quad{ }^{1}$ Department of Physics, Chemistry and Pharmacy, University of Southern Denmark, Campusvej

$6 \quad 55$, DK-5230 Odense M, Denmark

$7 \quad{ }^{2}$ Drug Metabolism and Pharmacokinetics, Janssen R\&D, Johnson \& Johnson, Turnhoutseweg 30,

8 BE-2340 Beerse, Belgium

$9 \quad{ }^{3}$ Drug Product Development, Janssen R\&D, Johnson \& Johnson, Turnhoutseweg 30, BE-2340

10 Beerse, Belgium

$11{ }^{4}$ Department of Science and Environment, Roskilde University, Universitetsvej 1, DK-4000

12 Roskilde, Denmark

13 *Corresponding author at: Department of Physics, Chemistry and Pharmacy, University of Southern

14 Denmark, Campusvej 55, DK-5230 Odense M, Denmark, phone: +45 6550 9427, e-mail:

15 cun@sdu.dk

16 Running title: MSH Particles increase digoxin exposure 


\section{Abstract}

In the small intestine, P-glycoprotein (P-gp) may limit the permeability of its substrates, which lead to reduced oral absorption. To circumvent the effect of P-gp, a nanocomposite material termed montmorillonite-surfactant hybrid particles was developed. The particles consisted of montmorillonite, the P-gp-inhibiting, nonionic surfactant, polysorbate 20, and the P-gp substrate, digoxin. The present study aimed to investigate if montmorillonite-surfactant hybrid particles could modulate the absorption of digoxin in vivo. Montmorillonite-surfactant hybrid particles were prepared by lyophilising an aqueous suspension of the constituents. Scanning electron microscopy (SEM), thermogravimetric analysis (TGA), and powder X-ray diffraction (PXRD) revealed an altered surface morphology, decreased water content, and intercalation of polysorbate 20 between montmorillonite layers. The particles were administered orally to Sprague Dawley rats, and digoxin was quantified by liquid chromatography-tandem mass spectrometry. Control digoxin-containing montmorillonite decreased the exposure of digoxin. In contrast, montmorillonite-surfactant hybrid particles increased AUC and $\mathrm{C}_{\max }$ by 31 and $91 \%$, respectively, compared to digoxin in solution. It was hypothesised

31 that montmorillonite-surfactant hybrid particles increased digoxin exposure by forming mucosa-

32 localised elevated concentrations of polysorbate 20 and digoxin, which enhanced the inhibitory effect of polysorbate 20 on P-gp.

Keywords: Intestinal absorption, montmorillonite, nanocomposites, digoxin, P-glycoprotein, polysorbate 20

Abbreviations: FWHM, the full width at half maximum; LBF, lipid-based formulation; MSH, 37 montmorillonite-surfactant hybrid, P-gp, P-glycoprotein; SPE, solid phase extraction.

38 List of compounds studied: Polysorbate 20, montmorillonite, digoxin. 


\section{Introduction}

40 Pharmacokinetic properties of drug substances have gained increased focus in early drug

41 development, as an estimated $10-20 \%$ of drug candidates fail in preclinical development or in clinical

42 trials, because of undesirable pharmacokinetic properties (Cook et al., 2014; Di and Kerns, 2016;

43 Kola and Landis, 2004). These undesirable pharmacokinetic properties are often caused by 44 P-glycoprotein (P-gp) (Di and Kerns, 2016), which is a widely expressed efflux transporter (Thiebaut et al., 1987). In the apical membrane of the intestinal epithelium, P-gp mediates cellular efflux of numerous drug substances, which leads to decreased absorption and bioavailability of the drug substance in question (Leslie et al., 2005; Lin and Yamazaki, 2003).

Numerous nonionic surfactants have been shown to inhibit P-gp in cell- and animal models, albeit in relatively high concentrations (Al-Ali et al., 2019; Cornaire et al., 2004; Lo, 2003; Zhang et al., 2003). Polysorbate 20 is among the most potent surfactant-based P-gp inhibitors investigated (Al-Ali et al., 51 2018a; Al-Ali et al., 2018b; Al-Saraf et al., 2016; Gurjar et al., 2018; Lo, 2003). Co-administration of $0.55 \mathrm{~g} \mathrm{~kg}^{-1}$ polysorbate 20 significantly increased the oral bioavailability of the P-gp substrate, digoxin, in rats from 59 to $84 \%$, and increased $\mathrm{C}_{\max }$ by $79 \%$ (Nielsen et al., 2016). Corresponding administration of digoxin to mdrla knockout rats produced an increased bioavailability, and there was no effect of co-administration of polysorbate 20 (Nielsen et al., 2016). This suggested that solubilising effects and/or increased passive permeability were not the cause of the increased absorption in wild type rats. However, a polysorbate 20 dose of $0.55 \mathrm{~g} \mathrm{~kg}^{-1}$ corresponds to a dose of approximately $6 \mathrm{~g}$ in humans, when a simple proportional weight scaling is applied (Nair and Jacob, 2016), i.e., more than thrice that of the WHO-recommended maximal daily dose of $25 \mathrm{mg} \mathrm{kg}^{-1}$

60 (Sheskey et al., 2017). Thus, there is a need to potentiate the effects of polysorbate 20 on P-gp to 61 develop an applicable polysorbate 20-based formulation for intestinal P-gp inhibition. 
In vitro, only $200 \mu \mathrm{M}\left(246 \mu \mathrm{g} \mathrm{mL}^{-1}\right)$ polysorbate 20 was required to completely inhibit P-gp-mediated

63 digoxin efflux in Caco-2 cells (Nielsen et al., 2016). Meanwhile, $10 \% \mathrm{v} / \mathrm{v}\left(110 \mathrm{mg} \mathrm{mL}^{-1}\right)$ polysorbate 20 in the dosing solution was necessary to produce the highest observed inhibition of intestinal P-gp activity, in vivo (Nielsen et al., 2016). This 450 -fold difference could be related to the fact that the in vitro transport system is stationary, while the intestinal lumen is a dynamic system with intestinal dilution, intestinal transit, and a redundancy in the area able to mediate absorption. Therefore, a formulation approach may be applied, in which polysorbate 20 and digoxin are released in the vicinity of the epithelial cells to modify the absorption process. We hypothesise that the clay nanomaterial, montmorillonite, can be applied as a drug substance- and excipient carrier in this context.

Montmorillonite has previously been investigated as a drug carrier (Aguzzi et al., 2007; Ruiz-Hitzky et al., 2010). Montmorillonite, like other clays, has a distinct layered structure and surface chemistry, and montmorillonite elicits a strong ability to retain cations (Hensen and Smit, 2002). Countless complex possibilities exist when montmorillonite is combined with for example polymers, surfactants, and dyes to form nanocomposites. Many potential applications have been investigated from wound dressings to food packaging and waste water treatment (Kokabi et al., 2007; Rhim et al., 2013; Wang and Wang, 2007). However, the application of montmorillonite-based nanocomposites has received limited attention in the pharmaceutical field. The most common approach has been to intercalate cationic drug substances between montmorillonite layers to obtain either a modulated drug release or a solubilising effect on the drug substance in question (Aguzzi et al., 2007). Neutral drug substances have also been shown to adsorb to montmorillonite surfaces via ion-dipole interactions (Su and Carstensen, 1972), and montmorillonite has been recognised as a possible solid carrier for lipid-based formulations (LBF) (Dening et al., 2017; Dening et al., 2018; Feeney et al., 2016). Calabrese and co-workers have successfully incorporated polysorbate 20 in montmorillonite to obtain delayed release of cinnamic acid (Calabrese et al., 2016; Calabrese et al., 2017), and they showed that 

polysorbate 20 facilitated the release of cinnamic acid from montmorillonite. Their studies also confirm the strong interactions between montmorillonite and polymers or surfactants that contain oxyethylene groups (- $\left.\mathrm{CH}_{2}-\mathrm{CH}_{2}-\mathrm{O}-\right)$, like polysorbate 20 (Aranda and Ruiz-Hitzky, 1992). Additionally, it has been shown that montmorillonite has mucoadhesive properties. For example, it was shown that montmorillonite intercalated with tetracycline displayed mucoadhesive forces to porcine mucus corresponding to $43 \%$ of chitosan, which is a known highly mucoadhesive polysaccharide (Iannuccelli et al., 2015). As a result, studies have focused on montmorillonite and composites hereof to obtain mucoadhesive drug delivery systems for gastroretention or local oral administration (Aguzzi et al., 2007; Calabrese et al., 2013; Iannuccelli et al., 2015; Onnainty et al., 2016).

Montmorillonite or other clay-based nanomaterials have not been investigated in pharmaceutical science to obtain modulation of intestinal drug transporters, to our knowledge. Based on literature findings that montmorillonite has mucoadhesive properties and displays modified drug substance release in combination with polysorbate 20 , we hypothesise that montmorillonite-surfactant hybrid (MSH) particles intercalated with polysorbate 20 and digoxin may lead to increased exposure of digoxin, compared to corresponding doses of polysorbate 20 and digoxin in simple solutions. The present study aimed to prepare and characterise MSH particles and to assess the pharmacokinetics of digoxin in rats after administration as MSH particles, compared to administration as simple solutions containing polysorbate 20 .

\section{Materials and methods}

\subsection{Materials}

Digoxin, triple deuterated $\left(\mathrm{D}_{3}\right)$-digoxin, polysorbate 20 , bovine serum albumin (albumin fraction $\mathrm{V}$ ) $>97 \%$, montmorillonite as 'nanoclay, hydrophilic bentonite', and all other chemicals in analytical grade quality or higher were from Merck KGaA (Germany). Ultrapure water was obtained from an 
110 in-house Milli-Q purification system (Millipore, MA, USA). Blank rat plasma was from 111 Bioreclamation IVT (NY, USA).

\section{$112 \quad 2.2 \quad$ Preparation of montmorillonite-surfactant hybrid particles}

113 MSH particles were prepared with a fixed 1:1 w/w ratio of montmorillonite and polysorbate 20 along 114 with an amount of digoxin that allowed a constant digoxin dose and variable doses of montmorillonite 115 and polysorbate 20 (Table 1). Furthermore, two control formulations were prepared. One contained montmorillonite and digoxin, designated digoxin-containing montmorillonite, and one contained only montmorillonite, designated lyophilised montmorillonite.

118 Suspensions of montmorillonite, polysorbate 20, and digoxin were obtained by suspending 119 montmorillonite in $11.0 \mathrm{~mL}$ ultrapure water (Milli-Q) in a beaker fitted with a magnet and stirred for $1204 \mathrm{~h}$. The $\mathrm{pH}$ was 9.5 after hydration of the montmorillonite suspension, and the $\mathrm{pH}$ was subsequently 121 adjusted to $7.0 \pm 0.1$ with $\mathrm{HCl}$. In parallel, polysorbate 20 was added to a screwcap vial together with $1000 \mu \mathrm{L}$ of a $1.00 \mathrm{mg} \mathrm{mL}^{-1}$ digoxin stock solution in $96 \% \mathrm{v} / \mathrm{v}$ ethanol. The mixture was ultrasonicated for 30 min to ensure solubilisation of digoxin using an Elmasonic P30H ultrasonic bath (Elma

124 Schmidbauer, Germany). $12.0 \mathrm{~mL}$ of ultrapure water was then added, and the polysorbate 20-digoxin mixture was ultrasonicated for $60 \mathrm{~min}$ to aid micelle formation. Then, the polysorbate 20-digoxin solution was added to the montmorillonite suspension dropwise ( $5 \mathrm{~min}$ ), and the resulting suspension was stirred for $24 \mathrm{~h}$ with the $\mathrm{pH}$ maintained at $7.5 \pm 0.5$ by manual addition of microvolumes of $1 \mathrm{M}$ $\mathrm{HCl}$. The suspension was divided into ten separate $10 \mathrm{~mL}$ lyophilisation vials and stored at $-20{ }^{\circ} \mathrm{C}$ 129 overnight. The frozen suspensions were lyophilised in a Beta 2-8 LSCBasic table top freeze dryer 130 (Martin Christ, Germany). Main drying lasted for $40 \mathrm{~h}$, applying a system pressure of $0.200 \mathrm{mbar}$, a 131 shelf temperature of $-25^{\circ} \mathrm{C}$, and a condenser temperature of approximately $-85^{\circ} \mathrm{C}$. The final drying 132 lasted for $4 \mathrm{~h}$, applying a system pressure of $0.011 \mathrm{mbar}$, a shelf temperature of $25^{\circ} \mathrm{C}$, and a condenser 133 temperature of approximately $-85^{\circ} \mathrm{C}$. Following lyophilisation, the chamber was filled with dry $\mathrm{N}_{2}$ 
134 gas, and the vials were quickly equipped with rubber stoppers. The total MSH particle content in each

135 vial was assessed by weighing the vial before filling and after lyophilisation. The products appeared 136 either as cakes or powders depending on the concentration of montmorillonite in the final suspensions 137 with increasing montmorillonite amounts resulting in a stable cake.

\section{$138 \quad 2.3 \quad$ Characterisation of MSH particles}

139 The MSH particles were characterised by scanning electron microscopy (SEM), thermogravimetric 140 analysis (TGA), and powder X-ray diffraction (PXRD).

\subsubsection{Scanning electron microscopy}

142 SEM was carried out with a Phenom ProX scanning electron microscope (Thermo Fisher Scientific, 143 MA, USA). A small amount of powder was mounted on $12 \mathrm{~mm}$ stubs with carbon tabs (Agar 144 Scientific, UK) and coated with gold by a Q150S rotary-pumped sputter coater-carbon coater 145 (Quorum, UK). Imaging was carried out at an accelerating voltage of $5 \mathrm{kV}$ at magnifications $146 \times 175-2900$ and $10 \mathrm{kV}$ at magnifications $\times 4300-29000$.

\subsubsection{Thermogravimetric analysis}

148 TGA was carried out on a Q500 thermogravimetric analyser (TA Instruments, TX, USA). Samples 149 of $2-4 \mathrm{mg}$ was equilibrated at $30^{\circ} \mathrm{C}$ for $2 \mathrm{~min}$ before the temperature was increased to $700{ }^{\circ} \mathrm{C}$ at a 150 rate of $10^{\circ} \mathrm{C} \mathrm{min}^{-1}$.

\subsubsection{Powder X-ray diffraction}

152 PXRD was carried out with a PANalytical X'pert PRO multipurpose diffractometer (Malvern 153 Panalytical, UK). Scanning was performed with a $\mathrm{Cu} \mathrm{K} \alpha, \lambda=1.5406 \AA$ radiation source in the $2 \theta$ 154 range from 3 to $50^{\circ}$ with a scan speed of $0.254^{\circ} \mathrm{s}^{-1}$ and a step size of $0.0167^{\circ}$. The voltage and 155 current were set to $45 \mathrm{kV}$ and $40 \mathrm{~mA}$, respectively. Samples were prepared on $16 \mathrm{~mm}$ zero 156 background plates. 
Miller indices were applied to describe the lattice planes in a sample that caused the observed reflections in powder X-ray diffractograms. A lattice plane can be described by three integers $(h k l)$, and the main interest of the present study was the (001) reflection, which is the reflection corresponding to the distance between two individual montmorillonite layers. Reflections caused by lattice planes within the individual montmorillonite layers, which were not related to interlayer distance, can be described as (hk0) reflections. The interlayer spacing of montmorillonite was calculated from the diffraction angles at maximum intensity of (001) reflections using Bragg's law:

$$
\mathrm{n} \lambda=2 \mathrm{~d} \sin (\theta)
$$

where $\mathrm{n}$ is the number of wavelengths, $\lambda$ is the wavelength of the $\mathrm{X}$-ray source, $\mathrm{d}$ is the interlayer spacing, and $\theta$ is the diffraction angle. Reflections were assigned by a comparison with literature (Viani et al., 2002). The full width at half maximum (FWHM) was estimated by manual readouts.

\subsection{In vivo study}

The study was carried out in accordance with European and Belgian law controlling the experiments on animals. 60 male Sprague Dawley rats (10 groups, $n=6)$ were supplied from Charles River (MA, USA) and acclimatised 11-12 days before conductance of the study. At the beginning of the study, the animals weighed 245-300 g (approximately 9 weeks of age) and were fasted for about $16 \mathrm{~h}$ prior to the experiment.

Animals were dosed by oral gavage with $5 \mathrm{~mL} \mathrm{~kg}^{-1}$ solutions or suspensions containing $0.02 \mathrm{mg} \mathrm{kg}^{-1}$ digoxin in $40 \%$ v/v ethanol in water. Dosing overview of the individual groups is shown in Table 2. The amount of ethanol administered did not affect the rats' clinical behaviour.

Blood samples were taken 15, 30, 45, 60, 120, 180, 240, and 360 min after administration. Micro sampling was performed by placing the rats in a restrainer and puncturing the tail vein with a $25 \mathrm{G}$ needle. $64 \mu \mathrm{L}$ of blood was then collected in a glass capillary (Vitrex Medical, Denmark) and closed 
in one end with a sigillum wax plate (Vitrex Medical, Denmark). Capillaries containing blood samples were placed in centrifuge tubes and kept on ice until centrifugation $\left(1900 \mathrm{G}, 4{ }^{\circ} \mathrm{C}, 10 \mathrm{~min}\right)$. After centrifugation, the clear part of the capillary, containing plasma, was cut off, and the plasma was transferred to two $10 \mu \mathrm{L}$ end-to-end pipettes (Vitrex Medical, Denmark) and placed in two individually labelled $1 \mathrm{~mL}$ Fluid X tubes (Brooks Life Sciences, MA, USA) with lids and stored in a 96-well format. Samples were kept at $-20{ }^{\circ} \mathrm{C}$ until analysis. The rats were euthanised after the last blood sample.

\subsubsection{Bioanalysis}

Calibration standards of digoxin were prepared in rat plasma to obtain concentrations of 2-100 ng mL $\mathrm{m}^{-1}$. Quality control samples of 8, 50, and $100 \mathrm{ng} \mathrm{mL} \mathrm{m}^{-1}$ solutions were prepared by spiking rat plasma with appropriate amounts of digoxin stock solution. Calibration standards and quality control samples were stored in $10 \mu \mathrm{L}$ end-to-end pipettes placed in Fluid X tubes and kept in a freezer $\left(-20^{\circ} \mathrm{C}\right)$ until sample preparation and were treated like the plasma samples as described below.

To wash out sample plasma from the end-to-end pipettes, $100 \mu \mathrm{L} 2 \% \mathrm{w} / \mathrm{v}$ bovine serum albumin in phosphate buffer ( $\mathrm{pH} 7.5$ ) was added to the sample tubes, and the samples were shaken horizontally (10 min, $\left.500 \mathrm{~min}^{-1}\right)$ and subsequently centrifuged $\left(5 \mathrm{~min}, 20^{\circ} \mathrm{C}, 2300 \times \mathrm{g}\right)$. A $55 \mu \mathrm{L}$ aliquot of the sample was then transferred to a new Fluid $\mathrm{X}$ tube, and $55 \mu \mathrm{L}$ internal standard $\left(25 \mathrm{ng} \mathrm{mL}^{-1} \mathrm{D}_{3}\right.$ digoxin in methanol) was added. The $\mathrm{pH}$ of the resulting mixture was adjusted to 9 by addition of 25 $\mu \mathrm{L}$ of a $2 \mathrm{M}$ ammonium acetate solution followed by dilution with $175 \mu \mathrm{L}$ Milli-Q purified water. The samples were shaken by vortex mixing after each addition.

Oasis ${ }^{\circledR}$ HLB 96 well solid phase extraction (SPE) plates, $30 \mu \mathrm{m}$ particle size, $30 \mathrm{mg}$ sorbent per well (Waters, MA, USA) were conditioned with $1 \mathrm{~mL}$ methanol, $1 \mathrm{~mL}$ Milli-Q purified water, and $3 \times 0.5$ mL 0.1 M ammonium acetate ( $\mathrm{pH}$ 9). Positive pressure ( 3 psi) was applied after each addition, until 
the resin was dry. Subsequently, the entire sample volume $(310 \mu \mathrm{L})$ was transferred to the conditioned

203 SPE well plates and positive pressure ( 1.5 psi) was applied to load the samples slowly. The SPE 204 wells were then washed with $3 \times 0.5 \mathrm{~mL} 0.1 \mathrm{M}$ ammonium acetate $(\mathrm{pH} 9)$. A positive pressure 205 ( 3 psi) was applied after each addition, until the resin was dry. The samples were then eluted from 206 the SPE resin with $2 \times 0.5 \mathrm{~mL}$ and $1 \times 0.2 \mathrm{~mL}$ ethanol into a new 96 -well plate. The eluent was then 207 dried under a $40 \mathrm{~L} \mathrm{~min}^{-1}$ flow of dry $\mathrm{N}_{2}$ at room temperature (Porvair Minivap, Porvair Sciences, UK) 208 and reconstituted in $300 \mu \mathrm{L} \mathrm{1:1} \mathrm{methanol:water} \mathrm{mixture} \mathrm{followed} \mathrm{by} \mathrm{vortex} \mathrm{mixing.} \mathrm{After} \mathrm{a}$ 209 centrifugation step $(10 \mathrm{~min}, 6000 \times \mathrm{g})$ the samples were transferred to a round 96-well plate for 210 chromatographic analysis.

211 Liquid chromatography-tandem mass spectrometry (LC-MS/MS) analysis was carried out on a 6500 212 Sciex triple quad instrument (ABSciex, Canada), which was coupled to a UHPLC-system (Shimadzu, 213 Japan). The chromatographic separation was carried out using a reversed phase UPLC column 214 (Acquity BEH C18, $1.7 \mu \mathrm{m}, 50 \times 2.1 \mathrm{~mm}$, Waters, MA, USA). The mobile phases consisted of $0.01 \mathrm{M}$ 215 ammonium carbonate (solvent A) and methanol (solvent B), and a gradient elution at $45^{\circ} \mathrm{C}$ was 216 performed (starting at $50 \%$ solvent A, $50 \%$ solvent B to $75 \%$ solvent B in 2.3 min, followed by 217 isocratic hold at $95 \% \mathrm{~B}$ for $1.19 \mathrm{~min}$ and re-equilibration to $50 \% \mathrm{~B}$ in $0.99 \mathrm{~min}$ ). Total run time was $2184.5 \mathrm{~min}$ and a flow rate of $0.3 \mathrm{~mL} \mathrm{~min}^{-1}$ was applied.

219 The LC-MS/MS was operated in positive ion mode using the TurboIonSpray ${ }^{\mathrm{TM}_{\text {-interface }}}$ 220 (electrospray ionisation), and was optimised for the quantification of digoxin, applying multiple 221 reaction monitoring $(\mathrm{m} / \mathrm{z}, 798.6 \rightarrow \mathrm{m} / \mathrm{z} 651)$.

222 The calibration curve ranged from 2-100 $\mathrm{ng} \mathrm{mL}^{-1}$ and linear regression with a weighing factor of $1 / \mathrm{x}^{2}$ 223 was used to produce the best fit for the concentration-detector response relationship. The lower limit 224 of quantification was $2 \mathrm{ng} \mathrm{mL}-1$. The accuracy of all batches, as measured by independent quality 
control samples, were between $80-120 \%$ of the nominal value over the entire range for the plasma samples.

\subsubsection{Data analysis}

228 The AUC of digoxin in the pharmacokinetic profile in the range 0-6 $\mathrm{h}$ was calculated by the 229 trapezoidal method. First order elimination was assumed, and the elimination rate constant $\left(\mathrm{k}_{\mathrm{e}}\right)$ of 230 digoxin was estimated by performing linear regression of $\mathrm{Ln}$ to the plasma concentrations as a 231 function of time using data points at $2,3,4$, and $6 \mathrm{~h}$. The slope of the resulting regression was $-\mathrm{k}_{\mathrm{e}} \cdot \mathrm{R}^{2}$ 232 values were generally above 0.90 . Plasma profiles were also fitted to zero order elimination with a 233 simple linear regression for the time points stated above. All formulations, except digoxin-containing 234 montmorillonite, displayed a higher $\mathrm{R}^{2}$ of the fit with first order elimination. It was assumed that the 235 formulations did not affect elimination, and that the difference observed for digoxin-containing 236 montmorillonite was caused by prolongation of absorption into the elimination phase, rather than 237 altered elimination. For this reason, plasma profiles for the treatment with digoxin-containing 238 montmorillonite was still analysed as first order elimination.

239 The $t_{1} / 2$ of digoxin was calculated:

$$
\mathrm{t}_{1 / 2}=\frac{\ln (2)}{\mathrm{k}_{\mathrm{e}}}
$$

240 Each analysis of $\mathrm{AUC}_{0-6 \mathrm{~h}}$ and elimination was performed for each individual data set, before statistical 241 analysis.

\subsubsection{Statistical analysis}

243 Statistical analysis was performed in GraphPad Prism 8.1.2. The pharmacokinetic parameters,

$244 \mathrm{AUC}_{0-6 \mathrm{~h}}, \mathrm{C}_{\max }$, the plasma concentration at the first sampling point $\left(\mathrm{C}_{15 \mathrm{~min}}\right)$, and $\mathrm{t}_{1 / 2}$ of each group of 245 animals were compared by one-way ANOVA, followed by a Dunnett's test in the following order: 246 Co-administration of the three doses of polysorbate 20 was compared to digoxin administered alone, 
and administration of MSH particles A-E was compared to both digoxin administered alone and to 248 digoxin-containing montmorillonite in two separate analyses. A student's t test was applied to 249 compare the pharmacokinetic parameters after administration of digoxin-containing montmorillonite 250 and digoxin only. All P-values below 0.05 were considered statistically significant.

\section{Results}

\subsection{Characterisation of MSH particles}

253 The untreated montmorillonite was light-brown or beige, as was the lyophilised- and digoxin254 containing montmorillonite formulations without polysorbate 20 . In contrast, polysorbate 20255 containing MSH particle formulations were more pale and had an off-white colour.

\subsubsection{Scanning electron microscopy}

257 The shape and surface morphology of the montmorillonite particles was investigated by SEM. 258 Untreated montmorillonite (Fig. 1A) contained pores of irregular shape with the observed perimeter 259 diameters in the range $0.8-2.5 \mu \mathrm{m}$. The surface morphology of digoxin-containing (Fig. 1B) and 260 lyophilised montmorillonite (Fig. S2B) appeared similar on the SEM images. Comparison of the SEM 261 images of untreated montmorillonite with lyophilised montmorillonite and digoxin-containing 262 montmorillonite, showed that lyophilisation resulted in a more porous structure with pore diameters 263 of $0.5-3 \mu \mathrm{m}$, which was also observed when polysorbate 20 was intercalated (Fig. 1C and D). 264 Additionally, when polysorbate 20 was intercalated, the pores and the appearance of the particle 265 surface for MSH particles changed to smoother and more circle- or ellipse-shaped pores, as compared 266 to digoxin-containing and lyophilised montmorillonite.

267 The particle shape changed from spheres to irregular particles with sharp edges upon lyophilisation 268 (Fig. S1). The observed perimeter diameter of the untreated montmorillonite particles was in the range 269 of 4-50 $\mu \mathrm{m}$. The irregular MSH particles and digoxin-containing montmorillonite was in the range of $2702-200 \mu \mathrm{m}$, while lyophilised montmorillonite was in the range of 2-500 $\mu \mathrm{m}$ (Fig. S2A). 


\subsubsection{Thermogravimetric analysis}

272 The composition and stability of the starting compounds and the prepared formulations were assessed by TGA (Fig. 2). The characteristic temperature intervals and corresponding thermogravimetric mass loss are given in Table S1. Untreated montmorillonite contained $11 \%$ physically adsorbed water and $4 \%$ interlayer water. Dehydroxylation of the untreated montmorillonite accounted for a $3 \%$ mass loss, resulting in a mass of $83 \%$ left in the pan after heating to $700{ }^{\circ} \mathrm{C}$ (residual mass). Polysorbate 20 contained $2 \%$ water and $96 \%$ mass was lost during degradation, which left a residual mass of $1 \%$.

Lyophilised and digoxin-containing montmorillonite contained less physically adsorbed water than untreated montmorillonite with 5 and $7 \%$, respectively, and $4 \%$ interlayer water. Furthermore, lyophilised and untreated montmorillonite displayed an $87 \%$ and $86 \%$ residual mass, respectively (Table S1). These residuals correspond to untreated montmorillonite, when corrected for water content.

MSH particles displayed an even lower content of both physically adsorbed water at $1 \%$ and interlayer water at $1 \%$. Degradation of polysorbate 20 led to a $53 \%$ mass loss, and montmorillonite dehydroxylation accounted for $1 \%$ mass loss, which resulted in a $45 \%$ residual, corresponding to montmorillonite content. Additionally, comparison of polysorbate 20 and $\mathrm{MSH}$ particles showed that polysorbate 20 decomposed at a lower temperature, when it was incorporated into MSH particles as the polysorbate 20 degradation was shifted approximately $35^{\circ} \mathrm{C}$ down.

\subsubsection{Powder X-ray diffraction}

290 The interlayer spacing of montmorillonite in the MSH particles was investigated by PXRD, as shown

291 in Fig. 3. The interlayer spacing, which was determined from the (001) reflection was $14.9 \AA$ in 292 untreated montmorillonite and increased to $18.0 \AA$ in MSH particles. The (001) reflection for 
was narrower with a FWHM of $1.00^{\circ}$. Additionally, the (002), (003), (005), and (006) reflections were present in the MSH particle diffractogram, but not in the untreated montmorillonite diffractogram. For both digoxin-containing montmorillonite and lyophilised montmorillonite, none 297 of the (00l) reflections were observed (Fig. 3).

298 At larger diffraction angles, all formulations showed reflections at approximately 20,35 , and $40^{\circ}$. 299 They can all be assigned to $(h k 0)$ reflections or combinations including these, which were all 300 independent of the orientation of the individual montmorillonite layers. Reflections at $29^{\circ}$ were only 301 present for untreated montmorillonite, digoxin-containing montmorillonite, and lyophilised 302 montmorillonite.

\section{$303 \quad 3.2 \quad$ In vivo study}

304 The pharmacokinetics of digoxin was investigated in male Sprague Dawley rats, when polysorbate 20 305 was co-administered in simple solutions and in MSH particles. The pharmacokinetic profiles are 306 shown in Fig. 4, while obtained pharmacokinetic parameters are summarised in Table 3. The effects 307 of the applied formulations were most notable on $\mathrm{C}_{\max }$ and $\mathrm{C}_{15 \text { min. }}$ Overall, the plasma concentration 308 of digoxin reached a maximum within the first $45 \mathrm{~min}$ (Table 3). Elimination generally followed first 309 order kinetics and there was no apparent correlation between formulation type and $t_{1} / 2$ (Table 3 ).

310 Formulations that contained polysorbate 20 in simple solutions did not alter $\mathrm{AUC}_{0-6 \mathrm{~h}}$. However, they 311 tended to decrease $t_{\max }$ and increase $C_{\max }$ and $C_{15}$ min of digoxin (Fig. 4A). $C_{15}$ min was increased in a 312 statistically significant manner for co-administration of 55 and $274 \mathrm{mg} \mathrm{kg}^{-1}$ polysorbate 20 (Table 3).

313 When digoxin was administered as digoxin-containing montmorillonite, a great alteration of the 314 pharmacokinetic profile was observed (Fig 4B). Administration of digoxin-containing 315 montmorillonite resulted in significantly lowered $\mathrm{AUC}_{0-6 \mathrm{~h}}, \mathrm{C}_{\max }$ and $\mathrm{C}_{15}$ min, compared to digoxin only

316 (Table 3), and $\mathrm{C}_{\max } / \mathrm{t}_{\max }$ could not clearly be defined (Fig 4B). 
In contrast, when digoxin was administered as MSH particles, containing montmorillonite and 318 polysorbate $20, \mathrm{AUC}_{0-6 \mathrm{~h}}, \mathrm{C}_{\mathrm{max}}$, and $\mathrm{C}_{15}$ min all increased 2-4-fold, compared to digoxin-containing 319 montmorillonite (Table 3). For doses of $137-548 \mathrm{mg} \mathrm{kg}^{-1}$ montmorillonite and polysorbate 20, these 320 increases were statistically significant. In concordance, the incorporation of polysorbate 20 also led 321 to decreased $t_{\max }$ (Table 3). Compared to digoxin administered alone, MSH particles increased $322 \mathrm{AUC}_{0-6 \mathrm{~h}}, \mathrm{C}_{\max }$ and $\mathrm{C}_{15 \mathrm{~min}}$, and the increase in $\mathrm{C}_{\max }$ and $\mathrm{C}_{15} \mathrm{~min}$ for the $548 \mathrm{mg} \mathrm{kg}^{-1} \mathrm{MSH}$ formulation 323 was statistically significant (Table 3).

324 In some cases, MSH particles also tended to increase both $\mathrm{AUC}_{0-6 \mathrm{~h}}$ and $\mathrm{C}_{\max }$ of digoxin, compared to 325 co-administration of polysorbate 20 in simple solutions in the corresponding doses. For example, co326 administration of $548 \mathrm{mg} \mathrm{kg}^{-1}$ polysorbate 20 as $\mathrm{MSH}$ particles increased $\mathrm{AUC}_{0-6 \mathrm{~h}}$ and $\mathrm{C}_{\max }$ of digoxin $32731 \%$ and $32 \%$, compared to co-administration of $548 \mathrm{mg} \mathrm{kg}^{-1}$ polysorbate 20 in a simple solution 328 (Fig. 4D).

\section{Discussion}

\subsection{Polysorbate 20 is intercalated in MSH particles}

331 The obtained MSH particles were solid, even though they consisted of $52 \%$ polysorbate 20, which 332 is liquid at room temperature. This phase transition may occur, because polysorbate 20 was adsorbed 333 to the montmorillonite surfaces. This was supported by the lighter colour of the MSH particles, which 334 indicated that polysorbate 20 coated the montmorillonite surface, as also reflected by the particle 335 morphology according to SEM. Lyophilised montmorillonite, digoxin-containing montmorillonite, 336 and MSH particles were subjected to the same lyophilisation cycle, but the total water content was 337 considerably lower in MSH particles. The lower interlayer water content suggested that the 338 intercalation of polysorbate 20 led to extrusion of water from the interlayer spaces. The destabilisation 339 of polysorbate 20, when incorporated in MSH particles, as indicated by TGA, was also observed by 
340 Calabrese and co-workers (Calabrese et al., 2016), and similar trends have been presented with similar 341 nanocomposites (Liu et al., 2003).

342 The structure of individual montmorillonite layers was conserved in all the samples, as evident by the 343 combined (hk0) reflections obtained with PXRD. The (001) reflection shifted to a lower diffraction 344 angle for MSH particles as compared to untreated montmorillonite, which implied an increased 345 interlayer distance from 14.9 to $18.0 \AA$. This $3.1 \AA$ increase agrees well with previous studies 346 (Calabrese et al., 2016; Calabrese et al., 2017). Under the assumption that the thickness of an 347 individual montmorillonite layer is $10 \AA$ (Ploehn and Liu, 2006), the resulting distance between 348 individual montmorillonite layers was 8 Å, corresponding to 5-6 C-C alkane bonds (Skinner, 1945). 349 This distance indicated a relatively flat conformation of polysorbate 20 , and effectively excluded the 350 possibility of micelle-like bilayer conformations or similar.

351 The (001) reflection was absent in digoxin-containing and lyophilised montmorillonite, which 352 implied exfoliation of montmorillonite layers as illustrated in Fig. 5. Furthermore, the appearance of 353 (002), (003), (005), and (006) and a narrower (001) reflection in the MSH particle diffractogram 354 suggested increased stacking order. Hence, lyophilisation of montmorillonite suspensions seems to 355 lead to exfoliation of individual layers. In contrast, when polysorbate 20 was introduced in the 356 preparation of MSH particles, which were subjected to the same lyophilisation cycle, montmorillonite 357 layers were not exfoliated. Instead, polysorbate 20 assisted in the stacking of montmorillonite layers 358 and increased the stacking order of montmorillonite layers.

359 The presence of the reflection at $29^{\circ}$ for untreated montmorillonite and digoxin-treated 360 montmorillonite and the absence of the same reflection for MSH particles has not conclusively been 361 understood. The reflection could simply have been overshadowed in the diffractogram of MSH 362 particles. 
363 Characterisation of MSH particles by SEM, PXRD, and TGA have proven a strong interaction 364 between polysorbate 20 and montmorillonite. Many different interactions between clays and organic 365 compounds have previously been described (Ruiz-Hitzky et al., 2010). Some of those are also 366 suggested here: i) ion-dipole interactions between oxyethylene $\left(-\mathrm{CH}_{2}-\mathrm{CH}_{2}-\mathrm{O}-\right)$ units of 367 polysorbate 20 and the negative surface charge of montmorillonite; ii) hydrogen bonding between 368 end hydroxyl groups of polysorbate 20 and the siloxane surface of montmorillonite.

\subsection{Polysorbate 20-containing solutions modulated digoxin pharmacokinetics}

370 The experimental design did not allow for thorough estimation of digoxin absorption rate constant 371 from the intestine, and for this reason, the first sampling point at 15 min was taken as a rough estimate 372 of absorption rate. Polysorbate 20 in the simple solution tended to increase $\mathrm{C}_{\max }$ and $\mathrm{C}_{15} \min$ and 373 decreased $t_{\max }$, which was also shown by Nielsen and co-workers in a previous study (Nielsen et al., 374 2016). However, in contrast to this previous study, no change was observed in $\mathrm{AUC}_{0-6 \mathrm{~h}}$ in the present 375 study. Overall, AUC-values were generally lower in the present study compared to the study by

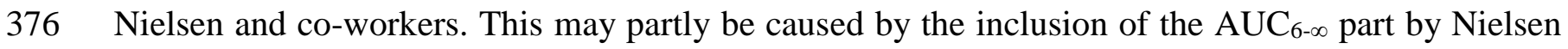
377 and co-workers, which was not included in the present study. The less pronounced effect of 378 polysorbate 20 on digoxin pharmacokinetics may also partly be attributed to differences in 379 quantification methods and variation between animals and raw materials. Variation of the 380 composition between brands and lots of polysorbate 20 is well-documented (Hewitt et al., 2011), 381 which may influence the function of polysorbate 20 as a P-gp inhibitor. Furthermore, previous studies 382 on inhibition of intestinal transporters and carriers have also shown a clear modulation of the 383 pharmacokinetic profile and effects on $\mathrm{C}_{\max }$ and $\mathrm{t}_{\max }$, but with no effects on AUC (Broberg et al., 384 2012; Nohr et al., 2014). When preceding evidence is considered, the present study still indicates that 385 polysorbate 20 modulated the pharmacokinetics of digoxin, despite limited statistical strength. The 
modulation of digoxin pharmacokinetics was ascribed to the inhibition of intestinal P-gp, leading to lowered efflux, and increased intestinal absorption of digoxin.

\subsection{Montmorillonite-surfactant hybrid particles increased digoxin exposure}

389 When digoxin-containing montmorillonite was administered, the $\mathrm{AUC}_{0-6 \mathrm{~h}}, \mathrm{C}_{\max }$, and $\mathrm{C}_{15}$ min decreased 390 compared to digoxin only, likely because of retention of digoxin by montmorillonite in the 391 formulation, which led to less digoxin available for absorption. This phenomenon has also been observed by Dening and co-workers (Dening et al., 2018) when the lipophilic and cationic drug substance, blonanserin, was intercalated into montmorillonite. Dening and co-workers investigated blonanserin release from montmorillonite in a USP dissolution setup, where only $13 \%$ was released after $12 \mathrm{~h}$. Accordingly, bioavailability in Sprague Dawley rats for montmorillonite-intercalated blonanserin was reduced by $35 \%$, compared to the pure drug suspension (Dening et al., 2018). The retention of digoxin in the present study showed that montmorillonite can also effectively adsorb uncharged drug substances. Therefore, montmorillonite alone appeared to be unsuitable for increasing oral digoxin absorption. Nevertheless, the lowering of digoxin exposure by 400 digoxin-containing montmorillonite was contrasted by the tendency of the MSH particles to increase 401 the exposure of digoxin. We therefore suggest that polysorbate 20 facilitated digoxin release from the 402 MSH particles and also inhibited P-gp activity, leading to an increased digoxin exposure. At present, 403 it was not possible to unequivocally distinguish these two effects from each other. Additionally, we 404 suggest that local co-release of digoxin and polysorbate 20 may have caused the observed increased 405 exposure by elevation of both polysorbate 20- and digoxin mucosal concentrations, compared to 406 polysorbate 20 and digoxin in simple solutions. However, neither the physicochemical 407 characterisation nor the in vivo performance of MSH particles have been able to confirm the 408 underlying mechanism, and further studies of the MSH particle-mucosa interaction are needed. 
409 When the effects of MSH particles and digoxin-containing montmorillonite are compared, 410 montmorillonite exhibited a dual function with respect to digoxin retention and enhancement of P-gp 411 inhibition. This was observed as a decreased digoxin exposure for digoxin-containing 412 montmorillonite, relative to control, but also as an enhancement of digoxin exposure, when 413 montmorillonite was intercalated with polysorbate 20 in MSH particles. The observed effects of 414 digoxin-containing montmorillonite and MSH particles in vivo and the proposed mechanisms have 415 been illustrated in Fig. 5.

416 Clays and other solid carriers have also been applied to solidify LBFs, and some examples exists, 417 where the solidified LBF outperforms the liquid LBF in vivo (Dening et al., 2018; Tan et al., 2013) 418 similarly to what have been observed in the present study. For example, a solidified silica-lipid hybrid 419 formulation of blonanserin tended to increase blonanserin AUC by $24 \%$, compared to a 420 corresponding medium-chain triglyceride solution (Dening et al., 2018).

421 In the present study, polysorbate 20 presented a dual function in MSH particles with the ability to 422 inhibit P-gp and to facilitate release of digoxin from montmorillonite surfaces. The facilitation of 423 drug release from montmorillonite by polysorbate 20 was also observed by Calabrese and co-workers 424 (Calabrese et al., 2017). $100 \%$ release of the anionic compound, cinnamic acid, was achieved after $4256 \mathrm{~h}$ from a montmorillonite-polysorbate 20 hybrid, whereas only $80 \%$ was released from pure 426 montmorillonite (Calabrese et al., 2017).

427 Digoxin-containing montmorillonite retained digoxin and decreased digoxin exposure, while MSH 428 particles increased digoxin exposure. Therefore, changing the ratio between montmorillonite and 429 polysorbate 20 in future formulations may produce enhanced polysorbate 20-mediated P-gp 430 inhibition leading to increased P-gp substrate exposure. 


\section{Conclusions}

432 The present study is the first to apply a surfactant-containing nanocomposite material to modulate an 433 intestinal efflux transporter, to our knowledge. Characterisation of MSH particles showed that 434 polysorbate 20 affected morphologic appearance of montmorillonite, was intercalated in the 435 interlayer spaces of montmorillonite, and that polysorbate 20 assisted in ordered stacking of 436 montmorillonite layers.

437 In vivo, MSH particles showed a tendency to increase digoxin exposure via P-gp inhibition, both 438 compared to digoxin administered alone and compared with co-administration of corresponding 439 polysorbate 20 doses in simple solutions. Furthermore, digoxin-containing montmorillonite, without 440 polysorbate 20, decreased digoxin exposure. This enhancement in digoxin exposure, when 441 administered as MSH particles, may be caused by mucosa-localised elevated concentrations of both 442 digoxin and polysorbate 20, which led to a more effective inhibition of P-gp. However, more research 443 is required to fully understand the underlying mechanism.

\section{Author information}

445 Author contribution

446 Conception and design of the study: RBN, AK, LD, KW, JS, UGN, RH, and CUN. Acquisition of 447 data: RBN and AK. Analysis and interpretation of data: RBN, AK, LD, KW, JS, UGN, RH, and CUN. 448 Drafting the article: RBN, UGN, RH, and CUN. Critical revising and final approval of the version 449 submitted: RBN, AK, LD, KW, JS, UGN, RH, and CUN.

450 ORCID

451 Rasmus Blaaholm Nielsen 0000-0003-1684-215X

452 Lieve Dillen 0000-0003-0573-9982

453 Jan Snoeys 0000-0003-3420-424X 
456 Notes: The authors declare no competing financial interests.

\section{$457 \quad 7$ Acknowledgements}

458 Researchers and technicians at Janssen R\&D and The University of Southern Denmark, who helped 459 set up, conduct, and analyse various experiments, including Bjarke Strøm Larsen, Maria Læssøe 460 Pedersen, Nicholai Daugaard Jensen, Dorthe Bomholdt Ravnsbæk, Tae-Hyun Kim, Dries 461 Versweyveld, Sanket Shah, Jasmine Bogaerts, Elene De Cleyn, Kore Van Mechelen, and Luc Sips 462 are hereby acknowledged.

463 The mobility action related to the project was financially supported by the Erasmus+ Programme, 464 Oticon Fonden, Knud Højgaards Fond, F.W. Frank og Hustru Angelina Franks Mindelegat, and 465 Henry og Mary Skovs Fond. 


\section{References}

468 Aguzzi, C., Cerezo, P., Viseras, C., Caramella, C., 2007. Use of clays as drug delivery systems: 469 Possibilities and limitations. Appl. Clay Sci. 36, 22-36. https://doi.org/10.1016/j.clay.2006.06.015.

Al-Ali, A.A.A., Nielsen, R.B., Steffansen, B., Holm, R., Nielsen, C.U., 2019. Nonionic surfactants modulate the transport activity of ATP-binding cassette (ABC) transporters and solute carriers (SLC): Relevance to oral drug absorption. Int. J. Pharm. 566, 410-433.

Al-Ali, A.A.A., Quach, J.R.C., Bundgaard, C., Steffansen, B., Holm, R., Nielsen, C.U., 2018a. Polysorbate 20 alters the oral bioavailability of etoposide in wild type and mdr1a deficient SpragueDawley rats. Int. J. Pharm. 543, 352-360. https://doi.org/10.1016/j.ijpharm.2018.04.006. digoxin absorption in Caco-2 and MDCKII MDR1 cells: Impact on P-glycoprotein inhibition, barrier function, and repeated cellular exposure. Int. J. Pharm. 551, 270-280. https://doi.org/10.1016/j.ijpharm.2018.09.039.

Al-Saraf, A., Holm, R., Nielsen, C.U., 2016. Tween 20 increases intestinal transport of doxorubicin in vitro but not in vivo. Int. J. Pharm. 498, 66-69. https://doi.org/10.1016/j.ijpharm.2015.12.017. Mater. 4, 1395-1403. https://doi.org/10.1021/cm00024a048.

Broberg, M.L., Holm, R., Tonsberg, H., Frolund, S., Ewon, K.B., Nielsen, A.L., Brodin, B., Jensen, 486 A., Kall, M.A., Christensen, K.V., Nielsen, C.U., 2012. Function and expression of the protoncoupled amino acid transporter PAT1 along the rat gastrointestinal tract: implications for intestinal absorption of gaboxadol. Br. J. Pharmacol. 167, 654-665. https://doi.org/10.1111/j.1476- 
490 Calabrese, I., Cavallaro, G., Lazzara, G., Merli, M., Sciascia, L., Liveri, M.L.T., 2016. Preparation 491 and characterization of bio-organoclays using nonionic surfactant. Adsorption 22, 105-116. https://doi.org/10.1007/s10450-015-9697-1.

493 Calabrese, I., Cavallaro, G., Scialabba, C., Licciardi, M., Merli, M., Sciascia, L., Liveri, M.L.T., 494 2013. Montmorillonite nanodevices for the colon metronidazole delivery. Int. J. Pharm. 457, 224495 236. https://doi.org/10.1016/j.ijpharm.2013.09.017.

496 Calabrese, I., Gelardi, G., Merli, M., Liveri, M.L.T., Sciascia, L., 2017. Clay-biosurfactant materials 497 as functional drug delivery systems: Slowing down effect in the in vitro release of cinnamic acid. 498 Appl. Clay Sci. 135, 567-574. https://doi.org/10.1016/j.clay.2016.10.039.

499 Cook, D., Brown, D., Alexander, R., March, R., Morgan, P., Satterthwaite, G., Pangalos, M.N., 500 2014. Lessons learned from the fate of AstraZeneca's drug pipeline: a five-dimensional framework. 501 Nat. Rev. Drug Discov. 13, 419. https://doi.org/10.1038/nrd4309.

502 Cornaire, G., Woodley, J., Hermann, P., Cloarec, A., Arellano, U., Houin, G., 2004. Impact of 503 excipients on the absorption of P-glycoprotein substrates in vitro and in vivo. Int. J. Pharm. 278, 504 119-131. https://doi.org/10.1016/j.ijpharm.2004.03.001.

505 Dening, T.J., Rao, S., Thomas, N., Prestidge, C.A., 2017. Montmorillonite-lipid hybrid carriers for 506 ionizable and neutral poorly water-soluble drugs: Formulation, characterization and in vitro 507 lipolysis studies. Int. J. Pharm. 526, 95-105. https://doi.org/10.1016/j.ijpharm.2017.04.063.

508 Dening, T.J., Thomas, N., Rao, S., van Looveren, C., Cuyckens, F., Holm, R., Prestidge, C.A., 509 2018. Montmorillonite and Laponite Clay Materials for the Solidification of Lipid-Based 510 Formulations for the Basic Drug Blonanserin: In Vitro and in Vivo Investigations. Mol. Pharm. 15, 511 4148-4160. https://doi.org/10.1021/acs.molpharmaceut.8b00555. 
Di, L., Kerns, E.H., 2016. Drug-Like Properties: Concepts, Structure Design and Methods from

513 ADME to Toxicity Optimization, 2nd ed. Academic Press, Boston, USA.

514 Feeney, O.M., Crum, M.F., McEvoy, C.L., Trevaskis, N.L., Williams, H.D., Pouton, C.W.,

515 Charman, W.N., Bergstrom, C.A.S., Porter, C.J.H., 2016. 50 years of oral lipid-based formulations:

516 Provenance, progress and future perspectives. Adv. Drug Deliv. Rev. 101, 167-194.

517 https://doi.org/10.1016/j.addr.2016.04.007.

518 Gurjar, R., Chan, C.Y.S., Curley, P., Sharp, J., Chiong, J., Rannard, S., Siccardi, M., Owen, A., 519 2018. Inhibitory Effects of Commonly Used Excipients on P-Glycoprotein in Vitro. Mol. Pharm. 520 15, 4835-4842. https://doi.org/10.1021/acs.molpharmaceut.8b00482.

521 Hensen, E.J.M., Smit, B., 2002. Why Clays Swell. J. Phys. Chem. B 106, 12664-12667.

522 https://doi.org/10.1021/jp0264883.

523 Hewitt, D., Alvarez, M., Robinson, K., Ji, J.Y., Wang, Y.J., Kao, Y.H., Zhang, T., 2011. Mixed-

524 mode and reversed-phase liquid chromatography-tandem mass spectrometry methodologies to study 525 composition and base hydrolysis of polysorbate 20 and 80. J. Chromatogr. A 1218, 2138-2145.

526 https://doi.org/10.1016/j.chroma.2010.09.057.

527 Iannuccelli, V., Maretti, E., Montorsi, M., Rustichelli, C., Sacchetti, F., Leo, E., 2015.

528 Gastroretentive montmorillonite-tetracycline nanoclay for the treatment of Helicobacter pylori

529 infection. Int. J. Pharm. 493, 295-304. https://doi.org/10.1016/j.ijpharm.2015.06.049.

530 Kokabi, M., Sirousazar, M., Hassan, Z.M., 2007. PVA-clay nanocomposite hydrogels for wound 531 dressing. Eur. Polym. J. 43, 773-781. https://doi.org/10.1016/j.eurpolymj.2006.11.030.

532 Kola, I., Landis, J., 2004. Can the pharmaceutical industry reduce attrition rates? Nat. Rev. Drug 533 Discov. 3, 711-715. https://doi.org/10.1038/nrd1470. 
534 Leslie, E.M., Deeley, R.G., Cole, S.P.C., 2005. Multidrug resistance proteins: role of P-

535 glycoprotein, MRP1, MRP2, and BCRP (ABCG2) in tissue defense. Toxicol. Appl. Pharmacol. 536 204, 216-237. https://doi.org/10.1016/j.taap.2004.10.012.

537 Lin, J.H., Yamazaki, M., 2003. Role of P-glycoprotein in pharmacokinetics - Clinical implications. 538 Clin. Pharmacokinet. 42, 59-98. https://doi.org/10.2165/00003088-200342010-00003.

539 Liu, T.X., Lim, K.P., Tjiu, W.C., Pramoda, K.P., Chen, Z.K., 2003. Preparation and characterization 540 of nylon 11/organoclay nanocomposites. Polymer 44, 3529-3535. https://doi.org/10.1016/s0032$541 \quad 3861(03) 00252-0$.

542 Lo, Y.I., 2003. Relationships between the hydrophilic-lipophilic balance values of pharmaceutical 543 excipients and their multidrug resistance modulating effect in Caco-2 cells and rat intestines. J. 544 Control. Release 90, 37-48. https://doi.org/10.1016/S0168-3659(03)00163-9.

545 Nair, A.B., Jacob, S., 2016. A simple practice guide for dose conversion between animals and 546 human. J. Basic Clin. Pharm. 7, 27-31. https://doi.org/10.4103/0976-0105.177703.

547 Nielsen, C.U., Abdulhussein, A.A., Colak, D., Holm, R., 2016. Polysorbate 20 increases oral 548 absorption of digoxin in wild-type Sprague Dawley rats, but not in mdr1a(-/-) Sprague Dawley rats. 549 Int. J. Pharm. 513, 78-87. https://doi.org/10.1016/j.ijpharm.2016.09.011.

550 Nohr, M.K., Thale, Z.I., Brodin, B., Hansen, S.H., Holm, R., Nielsen, C.U., 2014. Intestinal 551 absorption of the antiepileptic drug substance vigabatrin is altered by infant formula in vitro and in 552 vivo. Pharmacol. Res. Perspect. 2, e00036. https://doi.org/10.1002/prp2.36.

553 Onnainty, R., Onida, B., Paez, P., Longhi, M., Barresi, A., Granero, G., 2016. Targeted chitosan554 based bionanocomposites for controlled oral mucosal delivery of chlorhexidine. Int. J. Pharm. 509, 555 408-418. https://doi.org/10.1016/j.ijpharm.2016.06.011. 
556 Ploehn, H.J., Liu, C., 2006. Quantitative Analysis of Montmorillonite Platelet Size by Atomic Force 557 Microscopy. Ind. Eng. Chem. Res. 45, 7025-7034. https://doi.org/10.1021/ie051392r.

558 Rhim, J.W., Park, H.M., Ha, C.S., 2013. Bio-nanocomposites for food packaging applications.

559 Prog. Polym. Sci. 38, 1629-1652. https://doi.org/10.1016/j.progpolymsci.2013.05.008.

560 Ruiz-Hitzky, E., Aranda, P., Darder, M., Rytwo, G., 2010. Hybrid materials based on clays for 561 environmental and biomedical applications. J. Mater. Chem. 20, 9306-9321.

562 https://doi.org/10.1039/c0jm00432d.

563 Sheskey, P.J., Cook, W.G., Cable, C.G., 2017. Handbook of Pharmaceutical Excipients, 8th ed. 564 Pharmaceutical Press, London, UK.

565 Skinner, H.A., 1945. A revision of some bond-energy values and the variation of bond-energy with 566 bond-length. Trans. Faraday Soc. 41, 645-662. https://doi.org/10.1039/tf9454100645.

567 Su, K.S.E., Carstensen, J.T., 1972. Nature of bonding in montmorillonite adsorbates II: Bonding as 568 an ion-dipole interaction. J. Pharm. Sci. 61, 420-424. https://doi.org/10.1002/jps.2600610321.

569 Tan, A., Rao, S., Prestidge, C.A., 2013. Transforming Lipid-Based Oral Drug Delivery Systems 570 into Solid Dosage Forms: An Overview of Solid Carriers, Physicochemical Properties, and 571 Biopharmaceutical Performance. Pharm. Res. 30, 2993-3017. https://doi.org/10.1007/s11095-013$572 \quad \underline{1107-3 .}$.

573 Thiebaut, F., Tsuruo, T., Hamada, H., Gottesman, M.M., Pastan, I., Willingham, M.C., 1987.

574 Cellular localization of the multidrug-resistance gene product P-glycoprotein in normal human 575 tissues. Proc. Natl. Acad. Sci. U.S.A. 84, 7735-7738. https://doi.org/10.1073/pnas.84.21.7735.

576 Viani, A., Gaultieri, A.F., Artioli, G., 2002. The nature of disorder in montmorillonite by simulation 577 of X-ray powder patterns. Am. Mineral. 87, 966-975. https://doi.org/10.2138/am-2002-0720. 
578 Wang, L., Wang, A.Q., 2007. Adsorption characteristics of Congo Red onto the

579 chitelsan/montmorillonite nanocomposite. J. Hazard. Mater. 147, 979-985.

580 https://doi.org/10.1016/j.jhazmat.2007.01.145.

581 Zhang, H.J., Yao, M., Morrison, R.A., Chong, S.H., 2003. Commonly used surfactant, tween 80,

582 improves absorption of P-glycoprotein substrate, digoxin, in rats. Arch. Pharmacal Res. 26, 768583 772. https://doi.org/10.1007/bf02976689.

584

585 
587 Fig. 1: Representative scanning electron microscopy images of A) Untreated montmorillonite, B) 588 digoxin-containing montmorillonite, C) montmorillonite-surfactant hybrid (MSH) particles 589 formulation A, and D) MSH E. $\times 8700$ magnification. Scaling bar $=10 \mu \mathrm{m}$.

590 Fig. 2: Representative runs of thermogravimetric analysis of 2-4 mg aliquots of untreated 591 montmorillonite (MMT), lyophilised montmorillonite (Lyo-MMT), digoxin-containing 592 montmorillonite (DG-MMT), montmorillonite-surfactant hybrid particles (MSH), and polysorbate 20 593 (PS20). Equilibrated at $30{ }^{\circ} \mathrm{C}$, heated to $700{ }^{\circ} \mathrm{C}$ at a rate of $10{ }^{\circ} \mathrm{C} \mathrm{min}-1$.

594 Fig. 3: X-ray diffractograms and $h k l$-indexing of untreated montmorillonite (MMT), lyophilised montmorillonite (Lyo-MMT), digoxin-containing montmorillonite (DG-MMT), and montmorillonite-surfactant hybrid particles (MSH) formulation A (representative of all MSH formulations). Stacked diffractograms, dotted lines represent 0 for each one. Insert: Magnification of $3-8^{\circ} . \mathrm{Cu} \mathrm{K} \alpha$ radiation source $(\lambda=1.5406 \AA)$ over the range of $3-50^{\circ} 2 \theta$ with a scan speed of $0.254^{\circ}$ $599 \mathrm{~s}^{-1}$ and a step size of $0.0167^{\circ}$. Intensity in arbitrary units (a.u.).

600 Fig. 4: Time-concentration profiles of digoxin after oral administration of $0.2 \mathrm{mg} \mathrm{kg}^{-1}$ digoxin to 601 fasted male Sprague Dawley rats (245-300 g) as solutions or suspensions in $40 \% \mathrm{v} / \mathrm{v}$ ethanol in water. 602 Comparisons of A) digoxin administered alone in solution, with co-administration of 55, 274, or 548 $603 \mathrm{mg} \mathrm{kg}^{-1}$ polysorbate 20 (PS20), B) as digoxin-containing montmorillonite (DG-MMT, $548 \mathrm{mg} \mathrm{kg}^{-1}$ 604 MMT) or as montmorillonite-surfactant hybrid (MSH) particles containing 55-137 mg $\mathrm{kg}^{-1}$ 605 polysorbate 20 (PS20) and 55-137 $\mathrm{mg} \mathrm{kg}^{-1}$ montmorillonite (MMT) in a 1:1 ratio, and C) as 606 montmorillonite-surfactant hybrid (MSH) particles containing 274-548 $\mathrm{mg} \mathrm{kg}^{-1}$ MMT and 274-548 $607 \mathrm{mg} \mathrm{kg}^{-1}$ PS20 in a 1:1 ratio. D) is an additional representation of selected formulations for direct 
608 comparison. Values are given as mean \pm SEM, $n=6$. All lines are simple connecting lines for 609 overview.

610 Fig. 5. Illustration of the observed effects of the treatment of montmorillonite with digoxin (blue) or 611 digoxin and polysorbate 20 (red) prior to lyophilisation to form digoxin-containing montmorillonite 612 and montmorillonite-surfactant hybrid (MSH) particles, respectively. Digoxin-containing 613 montmorillonite is exfoliated (no stacking order), and MSH particles elicit increased stacking order 614 and an increase of interlayer distance from $14.9 \AA$ in untreated montmorillonite to $18.0 \AA$ A Overview 615 of the observed effects in vivo after oral administration of digoxin-containing montmorillonite and 616 montmorillonite-surfactant hybrid (MSH) particles.

617 Fig. S1: Scanning electron microscopy images of A) Untreated montmorillonite, B) digoxin618 containing montmorillonite, $\mathrm{C}$ ) montmorillonite-surfactant hybrid (MSH) particles formulation A and 619 D), MSH E. $\times 430$ magnification. Scaling bar $=200 \mu \mathrm{m}$.

620 Fig. S2: Scanning electron microscopy images of lyophilised montmorillonite. A) $\times 430$ and B) $\times 8700$ 621 magnification. Scaling bars $=10$ and $200 \mu \mathrm{m}$ respectively.

622 Table 1.

623 Table 2.

624 Table 3.

625 Table S1.

62610 Supplementary Material

627 *Fig. S1*

628 *Fig. S2*

$629 *$ Table $\mathrm{S} 1 *$ 


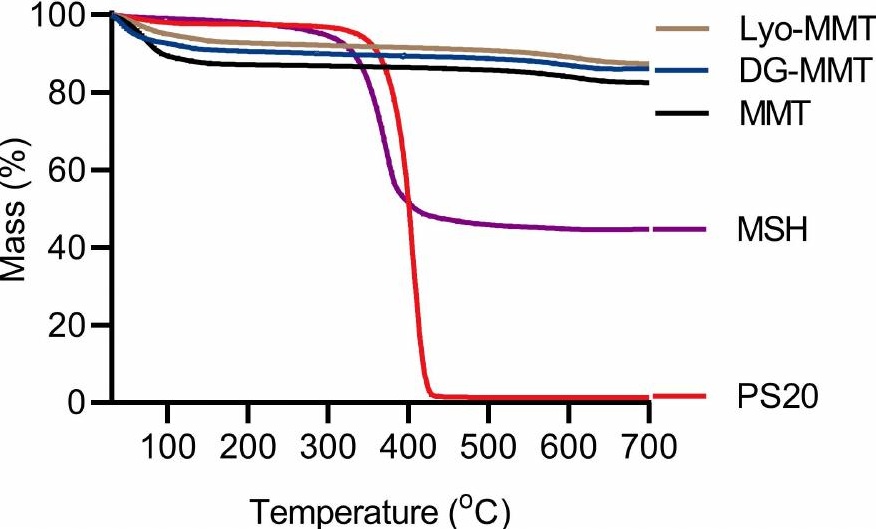




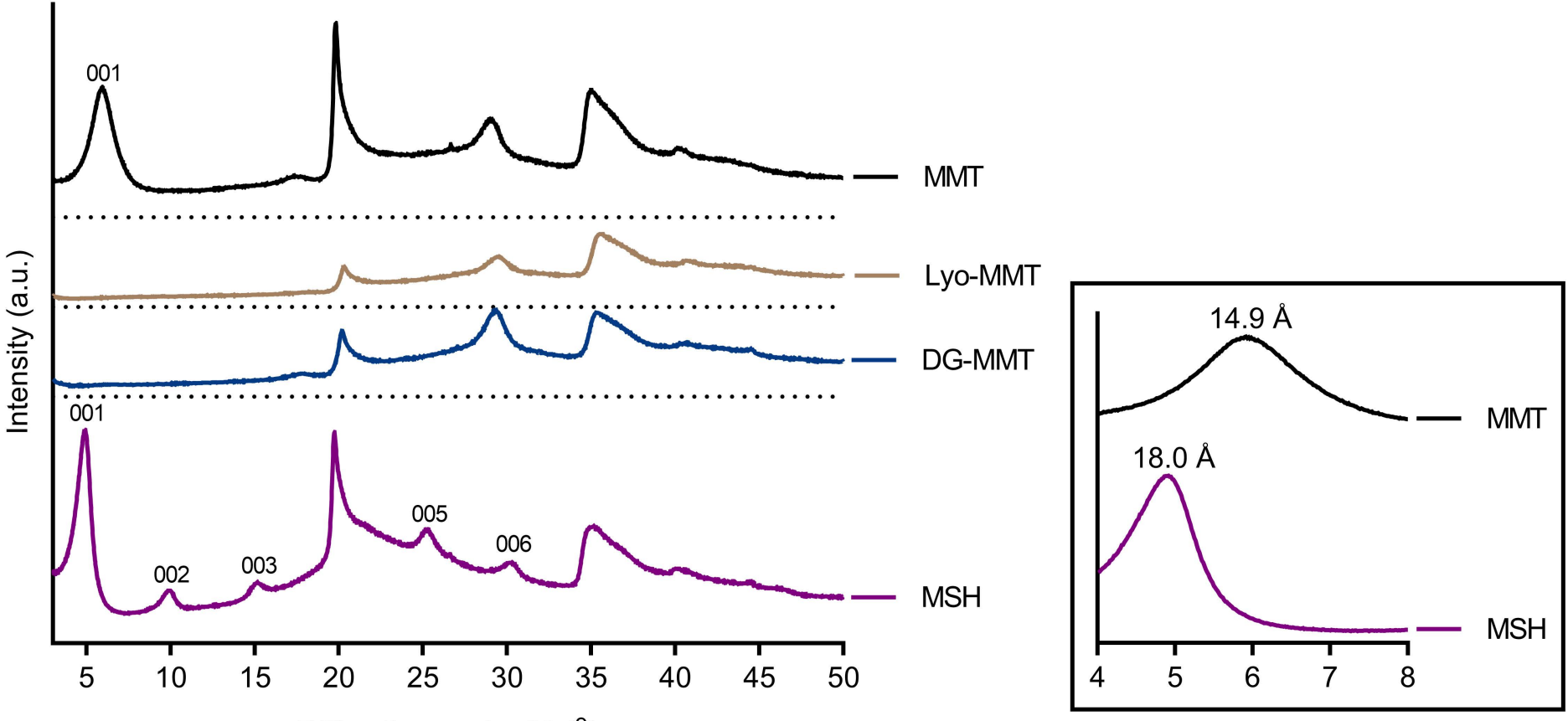

Diffraction angle, $2 \theta\left(^{\circ}\right)$ 


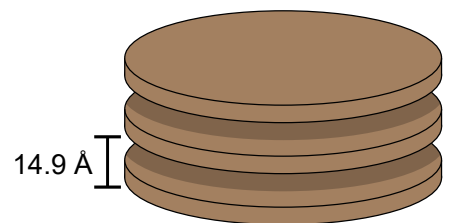

Montmorillonite

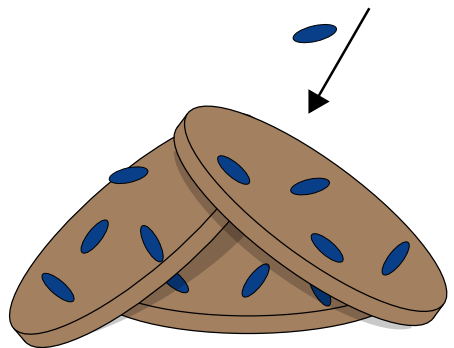

Digoxin-containing montmorillonite

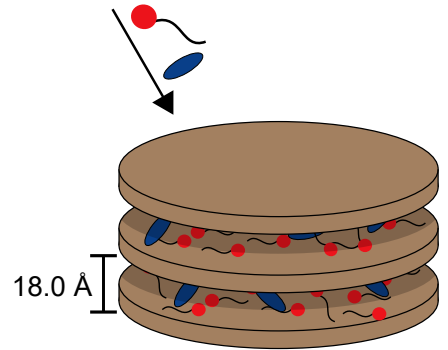

MSH particles
Digoxin adsorption to montmorillonite

Intestinal digoxin absorption

P-gp inhibition
Retention of digoxin

by montmorillonite

Lowered amount available for absorption

No effect
Digoxin release facilitated

by polysorbate 20

Increased absorption
Enhanced polysorbate 20-mediated

P-gp inhibition by local co-release 


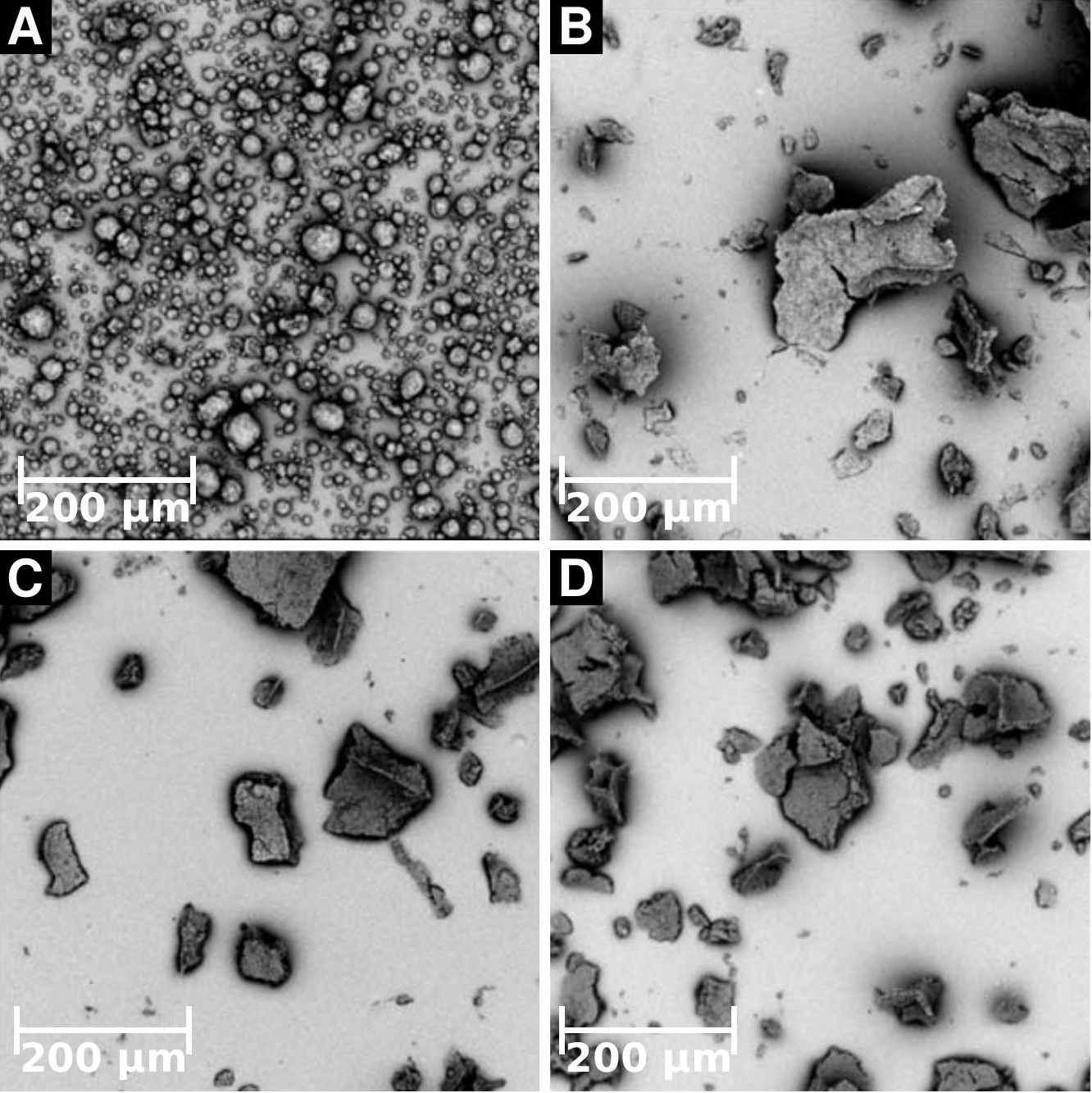




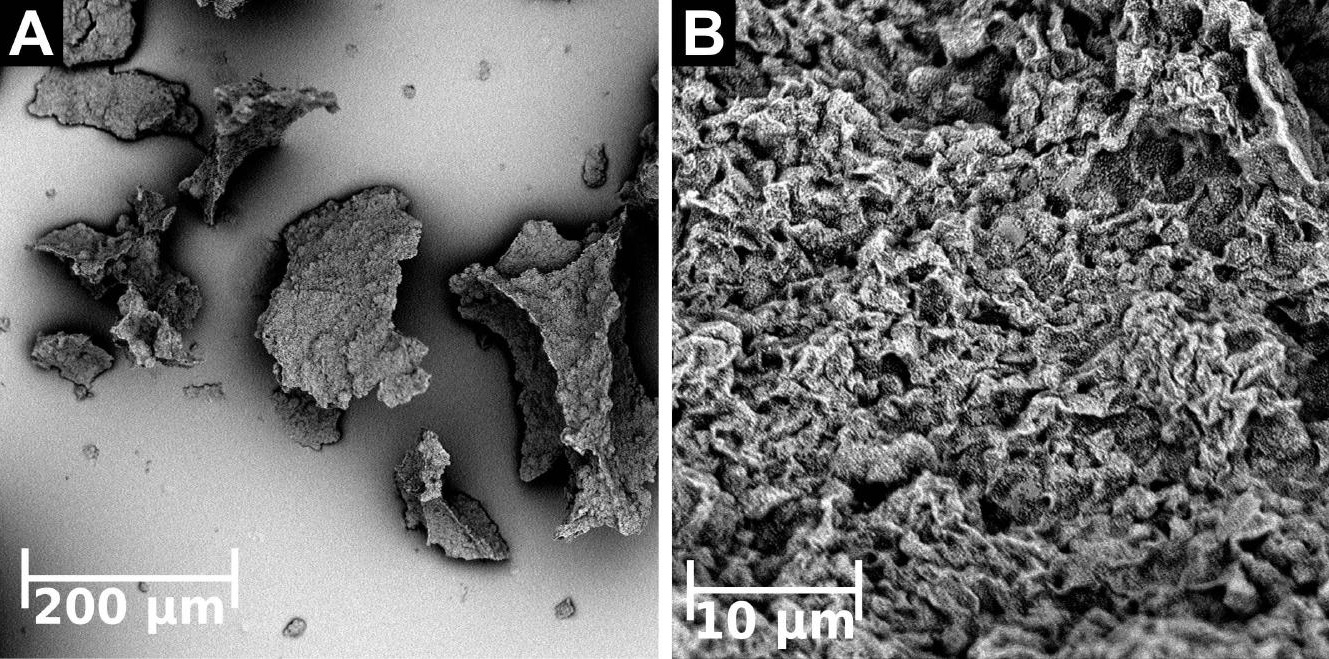


1 Digoxin

- Digoxin +

Montmorillonite

+ Digoxin

+ Digoxin

Polysorbate $20^{\circ}$
Montmorillonitesurfactant hybrid
$\mathrm{C}_{\text {max }}$ after

oral adm.
Digoxin-containing montmorillonite

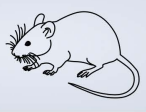


Table 1. Overview of prepared formulations

The prepared formulations including the added amounts of montmorillonite, polysorbate 20 , and digoxin as well as the calculated final content of these (\% w/w).

\begin{tabular}{|c|c|c|c|c|c|c|}
\hline \multirow{2}{*}{ Formulation } & \multicolumn{3}{|c|}{ Amount added (mg) } & \multicolumn{3}{|c|}{ Final content $(\% \mathrm{w} / \mathrm{w})$} \\
\hline & Montmorillonite & Polysorbate 20 & Digoxin & Montmorillonite & Polysorbate 20 & Digoxin \\
\hline MSH A & 2739 & 2750 & 1.00 & 50 & 50 & 0.018 \\
\hline MSH B & 2052 & 2051 & 1.00 & 50 & 50 & 0.024 \\
\hline MSH C & 1368 & 1372 & 1.00 & 50 & 50 & 0.036 \\
\hline MSH D & 679 & 689 & 1.00 & 50 & 50 & 0.073 \\
\hline MSH E & 273 & 275 & 1.00 & 50 & 50 & 0.182 \\
\hline $\begin{array}{l}\text { Lyophilised } \\
\text { montmorillonite }\end{array}$ & 2738 & - & - & 100 & - & - \\
\hline $\begin{array}{l}\text { Digoxin-containing } \\
\text { montmorillonite }\end{array}$ & 2738 & - & 1.00 & 100 & - & 0.037 \\
\hline
\end{tabular}


Table 2. In vivo study overview

Overview of administered dose of polysorbate 20, montmorillonite, and digoxin along with the amount of polysorbate 20 in the dosing formulation (\% v/v) for each group of male Sprague Dawley rats.

\begin{tabular}{|c|c|c|c|c|c|c|c|c|c|c|}
\hline Group number & 1 & 2 & 3 & 4 & 5 & 6 & 7 & 8 & 9 & 10 \\
\hline Formulation & & Sol & ion & & $\begin{array}{l}\text { Digoxin-containing } \\
\text { montmorillonite } \\
\text { suspension }\end{array}$ & \multicolumn{5}{|c|}{$\begin{array}{l}\text { MSH particle } \\
\text { suspension }\end{array}$} \\
\hline $\begin{array}{l}\text { Polysorbate } 20 \text { in dosing } \\
\text { formulation }(\% \mathrm{v} / \mathrm{v})\end{array}$ & - & 1 & 5 & 10 & - & 1 & 2.5 & 5 & 7.5 & 10 \\
\hline Digoxin dose (mg kg $\left.{ }^{-1}\right)$ & 0.2 & 0.2 & 0.2 & 0.2 & 0.2 & 0.2 & 0.2 & 0.2 & 0.2 & 0.2 \\
\hline Polysorbate 20 dose $\left(\mathrm{mg} \mathrm{kg}^{-1}\right)$ & - & 55 & 274 & 548 & - & 55 & 137 & 274 & 411 & 548 \\
\hline Montmorillonite dose (mg kg-1) & - & - & - & - & 548 & 55 & 137 & 274 & 411 & 548 \\
\hline
\end{tabular}

MSH, montmorillonite-surfactant hybrid 
Table 3. Estimated pharmacokinetic parameters.

\begin{tabular}{|c|c|c|c|c|c|}
\hline Formulation & $\begin{array}{c}\operatorname{AUC}_{0-6 \mathrm{~h}} \pm \text { SEM } \\
\left(\mu \mathrm{g} \min \mathrm{mL}^{-1}\right)\end{array}$ & 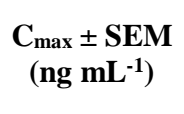 & $\begin{array}{l}\text { C15 min } \pm \text { SEM } \\
\quad\left(n g \mathbf{~ m L}^{-1}\right)\end{array}$ & $\begin{array}{c}\mathbf{t}_{\max } \\
{[\mathbf{Q 1 ; Q 3 ]}} \\
(\mathbf{m i n})\end{array}$ & $\begin{array}{l}\mathbf{t} 1 / 2 \pm \text { SEM } \\
\text { (h) }\end{array}$ \\
\hline Digoxin & $6.05 \pm 0.86$ & $29.6 \pm 4.9$ & $21.8 \pm 1.5$ & $\begin{array}{c}45 \\
{[30 ; 60]}\end{array}$ & $2.27 \pm 0.15$ \\
\hline + $55 \mathrm{mg} \mathrm{kg}^{-1}$ polysorbate 20 & $6.07 \pm 0.46$ & $43.8 \pm 4.1$ & $37.9 \pm 4.6^{*}$ & $\begin{array}{c}22.5 \\
{[15 ; 48.8]}\end{array}$ & $1.76 \pm 0.18$ \\
\hline + $274 \mathrm{mg} \mathrm{kg}^{-1}$ polysorbate 20 & $5.75 \pm 0.75$ & $41.1 \pm 4.0$ & $35.6 \pm 3.1^{*}$ & $\begin{array}{c}22.5 \\
{[15 ; 33.8]}\end{array}$ & $1.84 \pm 0.16$ \\
\hline + $548 \mathrm{mg} \mathrm{kg}^{-1}$ polysorbate 20 & $6.19 \pm 0.63$ & $42.6 \pm 6.9$ & $34.5 \pm 4.2$ & $\begin{array}{c}30 \\
{[15 ; 45]}\end{array}$ & $2.42 \pm 0.16$ \\
\hline $\begin{array}{l}\text { Digoxin-containing montmorillonite }\left(548 \mathrm{mg} \mathrm{kg}^{-1}\right. \\
\text { montmorillonite) }\end{array}$ & $2.78 \pm 0.21 *$ & $14.1 \pm 0.9^{*}$ & $12.6 \pm 1.2^{*}$ & $\begin{array}{c}37.5 \\
{[15 ; 48.8]}\end{array}$ & $2.78 \pm 0.34$ \\
\hline MSH (55 mg kg ${ }^{-1}$ montmorillonite \& polysorbate 20 ) & $5.14 \pm 0.34^{\#}$ & $33.0 \pm 2.4$ & $27.9 \pm 3.5$ & $\begin{array}{c}30 \\
{[15 ; 45]}\end{array}$ & $2.46 \pm 0.25$ \\
\hline MSH (137 mg kg-1 montmorillonite \& polysorbate 20 ) & $6.81 \pm 0.59^{\#}$ & $51.2 \pm 8.0^{\#}$ & $37.3 \pm 4.3^{\#}$ & $\begin{array}{c}37.5 \\
{[30 ; 45]}\end{array}$ & $2.54 \pm 0.36$ \\
\hline MSH (274 $\mathrm{mg} \mathrm{kg}^{-1}$ montmorillonite \& polysorbate 20 ) & $6.58 \pm 0.66^{\#}$ & $50.8 \pm 7.5^{\#}$ & $49.9 \pm 7.9 * \#$ & $\begin{array}{c}15 \\
{[15 ; 22.5]}\end{array}$ & $1.99 \pm 0.15$ \\
\hline MSH (411 mg kg ${ }^{-1}$ montmorillonite \& polysorbate 20) & $7.71 \pm 0.88^{\#}$ & $46.7 \pm 8.5^{\#}$ & $38.6 \pm 6.1^{\#}$ & $\begin{array}{c}37.5 \\
{[15 ; 48.8]}\end{array}$ & $2.30 \pm 0.19$ \\
\hline MSH (548 mg kg ${ }^{-1}$ montmorillonite \& polysorbate 20) & $7.94 \pm 0.66^{\#}$ & $56.4 \pm 9.0 * \#$ & $41.1 \pm 4.5^{* \#}$ & $\begin{array}{c}30 \\
{[30 ; 45]}\end{array}$ & $1.94 \pm 0.08$ \\
\hline
\end{tabular}

$\mathrm{C}_{15}$ min, the plasma concentration at the first sampling point (15 min); MSH, montmorillonite-surfactant hybrid particles. $\mathrm{t}_{\max }$ is given as median $\left[25^{\text {th }}\right.$ percentile; $75^{\text {th }}$ percentile]. Significantly different from digoxin only marked by $*$ and significantly different from digoxin-containing montmorillonite marked by ${ }^{*}(\mathrm{p}<0.05)$. 
Table S1. Thermogravimetric mass loss of applied formulations by temperature intervals.

\begin{tabular}{|c|c|c|c|c|c|}
\hline \multirow{3}{*}{ Formulation } & \multicolumn{5}{|c|}{ Mass lost (\%) in temp. interval } \\
\hline & $30-100{ }^{\circ} \mathrm{C}$ & $100-160^{\circ} \mathrm{C}$ & $160-500{ }^{\circ} \mathrm{C}$ & $500-700{ }^{\circ} \mathrm{C}$ & $700{ }^{\circ} \mathrm{C}$ \\
\hline & $\begin{array}{l}\text { Evap. adsorbed } \\
\text { water }\end{array}$ & $\begin{array}{l}\text { Evap. interlayer } \\
\text { water }\end{array}$ & $\begin{array}{l}\text { Evap. interlayer } \\
\text { water }+ \\
\text { polysorbate } 20 \\
\text { decomp. } \\
\end{array}$ & $\begin{array}{l}\text { Montmorillonite } \\
\text { dehydroxylation }\end{array}$ & Residual \\
\hline $\begin{array}{l}\text { Untreated } \\
\text { montmorillonite }\end{array}$ & 10.6 & 2.0 & 1.6 & 3.3 & 82.5 \\
\hline $\begin{array}{l}\text { Lyophilised } \\
\text { montmorillonite }\end{array}$ & 5.0 & 1.9 & 2.3 & 3.4 & 87.4 \\
\hline $\begin{array}{l}\text { Digoxin-containing } \\
\text { montmorillonite }\end{array}$ & 7.4 & 1.7 & 2.2 & 2.6 & 86.1 \\
\hline Polysorbate 20 & 2.0 & 0.3 & 96.3 & 0.0 & 1.4 \\
\hline MSH particles & 0.9 & 0.5 & 52.7 & 1.2 & 44.7 \\
\hline \multicolumn{6}{|c|}{ MSH, montmorillonite-surfactant hybrid. The defined intervals were ascribed to evaporation (ev } \\
\hline
\end{tabular}

